\title{
Atrial Natriuretic Factor Significantly Contributes to the Mineralocorticoid Escape Phenomenon

\author{
Evidence for a Guanylate Cyclase-mediated Pathway
}

Naoto Yokota, Benoit G. Bruneau, Mercedes L. Kuroski de Bold, and Adolfo J. de Bold

University of Ottawa Heart Institute at the Ottawa Civic Hospital, Ottawa, Ontario KIY 4E9, Canada

\begin{abstract}
The mechanism underlying the mineralocorticoid escape phenomenon remains unknown. To assess the possible contribution of natriuretic peptides to mineralocorticoid escape, rats were injected with $5 \mathrm{mg}$ deoxycorticosterone acetate for $3 \mathrm{~d}$. Plasma atrial natriuretic factor (ANF) rose to twice basal levels and atrial ANF content decreased significantly by $24 \mathrm{~h}$ of treatment. This coincided with renal escape and with a significant increase in urinary cGMP excretion. Plasma ANF remained elevated and atrial ANF content continued to decline by 48 and $72 \mathrm{~h}$ while atrial ANF mRNA levels increased significantly only at 72 h. Plasma brain natriuretic peptide did not increase during escape although atrial brain natriuretic peptide mRNA levels increased significantly. Chronically administered HS-142-1 (HS), a specific antagonist of the guanylate cyclase-coupled natriuretic peptide receptors, significantly and dose-dependently impaired the escape phenomenon. The highest dose of HS completely suppressed the increase in urinary cGMP. Despite the continued suppression, partial escape was observed by the end of the observation period. HS alone influenced neither plasma nor tissue or urine parameters. These findings show that despite activation of atrial ANF, blockade of the guanylate cyclase-coupled natriuretic peptide receptors impairs the ability of the kidney to escape the $\mathrm{Na}^{+}$retaining effect of excess mineralocorticoid in a dose-dependent fashion. Later-acting, unknown mechanisms eventually come into play to mediate the escape phenomenon through a guanylate cyclase-independent pathway. Therefore, ANF of cardiac origin appears to be a major factor initiating mineralocorticoid escape through a guanylate cyclase-dependent pathway. (J. Clin. Invest. 1994. 94:1938-1946.) Key words: atrial natriuretic factor $\bullet$ brain natriuretic peptide $\bullet$ deoxycorticosterone acetate escape $\bullet$ HS-142-1 • cyclic GMP
\end{abstract}

\section{Introduction}

Chronic exposure to either endogenous or exogenous mineralocorticoid excess results in a transient period of positive sodium

Address correspondence to Adolfo J. de Bold, Ph.D., University of Ottawa Heart Institute at the Ottawa Civic Hospital, 1053 Carling Avenue, Ottawa, Ontario K1Y 4E9, Canada.

Received for publication 22 February 1994 and in revised form 28 June 1994.

J. Clin. Invest.

(C) The American Society for Clinical Investigation, Inc.

0021-9738/94/11/1938/09 \$2.00

Volume 94, November 1994, 1938-1946 balance that is followed by a brisk natriuresis leading to the normalization of sodium balance despite the fact that the specific effects of mineralocorticoid on sodium transport at the level of the cortical collecting duct $(\mathrm{CCD})^{1}$ are not inhibited (1). The ability of the kidney to "escape" the continued sodium-retaining effects of mineralocorticoid excess has been the subject of extensive investigation, leading to several mechanistic explanations including increases in systemic arterial pressure (2), GFR (3), renal perfusion pressure (4), renal peritubular capillary and interstitial hydrostatic pressure (5), and renal prostaglandins and kinins $(6,7)$, as well as decreases in the levels of angiotensin II (8), renal sympathetic nerve activity (9), and renomedullary papillary osmolality (10). However, a significant number of reports have failed to find complete support for many of the above mechanisms $(6-8,11-16)$ and have, therefore, left open the question as to the existence of alternative or complementary mechanisms.

Atrial natriuretic factor (ANF) $(17,18)$ is a member of the natriuretic peptide family together with brain natriuretic peptide (BNP) (19) and C-type natriuretic peptide (20). ANF markedly increases renal sodium excretion and urinary volume despite an attendant decrease in systemic arterial pressure (17). Several reports have shown a preceding or coincidental rise in plasma ANF during mineralocorticoid escape, both in animals $(15,21-$ $24)$ and in humans $(12,13,25)$. Further, elevated plasma ANF has been found in patients with primary hyperaldosteronism in which congestive heart failure is not part of the syndrome (26). These observations suggest a role for this hormone in mineralocorticoid escape.

BNP is the second member of the family of natriuretic peptides (19). BNP shares with ANF a spectrum of biological properties (27). However, little is known about the response of BNP after mineralocorticoid excess, and the role of this peptide in mineralocorticoid escape remains unknown. The third natriuretic peptide, C-type natriuretic peptide, initially thought restricted to the nervous system, is not an effective natriuretic agent (20).

It is currently accepted that the effects of natriuretic peptides are mainly exerted through cellular events that include the binding of the hormone to specific receptors, activation of two types of membrane particulate guanylate cyclases (GC-A or ANFA receptor, and GC-B or ANF-B receptor), and elevation of intracellular cGMP levels $(28,29)$. In the microdissected nephron segments, mRNA for GC-A receptor has been identified

1. Abbreviations used in this paper: ANF, atrial natriuretic factor; BNP, brain natriuretic peptide; DOCA, deoxycorticosterone acetate; GC-A, guanylate cyclase-coupled type A natriuretic peptide receptor; HS, HS142-1; ir, immunoreactive; PGK, phosphoglycerate kinase; $U_{\text {cGMP }} V$, urinary cyclic GMP excretion; $U_{K} V$, urinary potassium excretion; $U_{N a} V$, urinary sodium excretion; UV, urinary volume. 
along the various sites (30). ANF and BNP have a similar potency for cGMP production reflecting the approximately equal binding affinity to the GC-A receptor for these peptides $(31,32)$.

The lack of specific antagonists for the guanylate cyclasecoupled natriuretic peptide receptors has been a major impediment in determining the role of natriuretic peptides. Attempts to confirm a participatory role of ANF in the mineralocorticoid escape phenomenon using passive immunization with anti-ANF antiserum have produced conflicting results $(22,33)$. However, recently, Morishita et al. (34) isolated the natriuretic peptide receptor antagonist HS-142-1 (HS) from a culture broth of Aureobasidium pullulans melangimum var. By use of affinity crosslinking they demonstrated that HS binds only to the guanylate cyclase-coupled, $135-\mathrm{kD}$ ANF receptor in bovine adrenocortical membrane and not to the $60-\mathrm{kD}$ guanylate cyclasefree clearance receptors in bovine lung membranes (35). It was also reported that $\mathrm{HS}$ selectively inhibits the binding of ${ }^{125} \mathrm{I}$ ANF to ANF bioactive receptors in the kidney cortex (34) and inhibits ANF- or BNP-induced cGMP production in various cell types in a dose-dependent manner (36). Furthermore, the effects of ANF and BNP on diuresis and urinary sodium and cGMP excretion in anesthetized rats were significantly reduced by pretreatment with $0.3 \mathrm{mg} / \mathrm{kg}$ HS (37). These findings demonstrate that HS is a specific antagonist of guanylate cyclasecoupled natriuretic peptide receptors and its in vivo application seems to be suitable for further establishing the physiological and pathophysiological roles of endogenous natriuretic peptides, including the mineralocorticoid escape phenomenon. Accordingly, we have studied the effects of chronically administered HS on the mineralocorticoid escape phenomenon induced by deoxycorticosterone acetate (DOCA) injection in terms of changes induced in plasma and cardiac tissue ANF and BNP peptide and relative mRNA content, as well as renal excretory function as measured by urine volume and electrolyte and cGMP excretion.

\section{Methods}

\section{Experimental protocols}

Adult male Sprague-Dawley rats, weighing 250-270 g, were kept in individual metabolic cages for $7 \mathrm{~d}$ before the start of experiments. The room was maintained at constant temperature $\left(24 \pm 1^{\circ} \mathrm{C}\right)$ and humidity $(60 \pm 3 \%)$ with a $12 \mathrm{~h}: 12 \mathrm{~h}$ light/dark cycle. Rats were fed $24 \mathrm{~g}$ of a diet (Zeigler Brothers Inc., Gardners, PA), formulated to contain $0.09 \%$ sodium and $0.38 \%$ potassium, thus providing $\sim 700 \mu \mathrm{mol}$ sodium and $2,000 \mu \mathrm{mol}$ potassium daily. The animals were allowed free access to deionized water. HS, provided by Kyowa Hakko Kogyo Co. Ltd. (Tokyo, Japan), was manufactured into special pellets (Innovative Research of America, Toledo, $\mathrm{OH}$ ) designed to release $0.15,0.3$, or 0.6 $\mathrm{mg}$ of $\mathrm{HS} / \mathrm{h}$ over $72 \mathrm{~h}$.

DOCA animals. In the first group of animals (DOCA group) ( $n$ $=5$ ), placebo pellets were implanted subcutaneously under halothane anesthesia. After complete recovery, daily injections of $5 \mathrm{mg}$ DOCA (Sigma Chemical Co., St. Louis, MO) dissolved in $100 \mu \mathrm{l}$ of sesame oil were given subcutaneously to the animals at 9:00 am for $3 \mathrm{~d}$ (DOCA group). To examine the time course of changes in plasma levels and cardiac natriuretic peptide and mRNA contents, rats were killed by decapitation at $0,12,24$, and $48 \mathrm{~h}$ after the first DOCA injection $(n=$ 5 for each time point). Another group of animals treated as above ( $n$ $=5$ ) were placed in metabolic cages over $72 \mathrm{~h}$ and urine was collected at 9:00 am every $24 \mathrm{~h}$. All animals in this group were killed at $72 \mathrm{~h}$ for biochemical measurements. Urine collected for each of $2 \mathrm{~d}$ before the commencement of the treatment was used to determine basal values and the first 24-h period after the beginning of the DOCA treatment is referred to as the first day.

DOCA + HS animals. In the second group of animals (DOCA + HS group), pellets designed to release different doses of HS as indicated above ( $n=5$ for each dose) were implanted subcutaneously. The animals were then injected with $5 \mathrm{mg}$ DOCA for $3 \mathrm{~d}$. Urine was collected as described for the DOCA group and the animals were killed at $72 \mathrm{~h}$.

$H S$ animals. A group of five animals (HS group) was implanted with pellets releasing $0.6 \mathrm{mg} / \mathrm{h}$ of $\mathrm{HS}$ and injected with the DOCA vehicle. Sample collection was carried out as for the DOCA group.

\section{Plasma and tissue sampling}

Trunk blood was collected in ice-chilled tubes containing $1.5 \mathrm{mg} / \mathrm{ml}$ EDTA- $\mathrm{Na}_{2}$ and $500 \mathrm{kIU} / \mathrm{ml}$ aprotinin. The plasma samples, obtained after centrifugation at $1,500 \mathrm{~g}$ for $20 \mathrm{~min}$ at $4^{\circ} \mathrm{C}$, were kept at $-80^{\circ} \mathrm{C}$ until assayed. The hearts were rapidly excised, and the atria and ventricles were dissected. To avoid atrial contamination, ventricular tissue samples were obtained from the apex of the heart. The tissue samples were immediately frozen in liquid nitrogen, and kept at $-80^{\circ} \mathrm{C}$ until peptide or RNA extraction.

\section{Extraction of plasma and tissue samples}

Plasma samples were acidified by adding $100 \mu \mathrm{l} / \mathrm{ml}$ of $1 \mathrm{~N} \mathrm{HCl}$ and passed through Sep-Pak $\mathrm{C}_{18}$ cartridges (Millipore-Waters Corp., Milford, MA) that were prewetted with $5 \mathrm{ml}$ of acetonitrile and rinsed with $20 \mathrm{ml}$ of $0.1 \%$ trifluoroacetic acid. After plasma processing, the cartridges were washed with $20 \mathrm{ml}$ of $0.1 \%$ trifluoroacetic acid (38), and then eluted with $3 \mathrm{ml}$ of $60 \%$ acetonitrile in $0.1 \%$ trifluoroacetic acid. Tissue samples were homogenized in $10 \mathrm{vol}$ of an extracting mixture consisting of $0.1 \mathrm{~N} \mathrm{HCl}, 1.0 \mathrm{M}$ acetic acid, and $1 \% \mathrm{NaCl}$, and centrifuged at $10,000 \mathrm{~g}$ for $30 \mathrm{~min}$ at $4^{\circ} \mathrm{C}$. The supernatants were then extracted using Sep-Pak $\mathrm{C}_{18}$ cartridges as described above for plasma.

\section{Total RNA extraction and Northern blot analysis}

Atrial and ventricular tissue samples from individual rats $(n=5$ for each time point, each group) were extracted using Ultraspec ${ }^{\mathrm{TM}}$ (Biotecx Laboratories, Houston, TX) according to the manufacturer's directions using a ratio of $100 \mathrm{mg}$ tissue/ml solution. Total RNA from the atria $(10 \mu \mathrm{g})$ and ventricle $(20 \mu \mathrm{g})$ were electrophoretically separated in an agarose-formaldehyde gel, followed by blotting to nylon membranes (Hybond N+, Amersham Corp., Oakville, Ontario, Canada) overnight. PCR cloning of the BNP cDNA, hybridization conditions, and autoradiographic procedures have been described previously (39). Autoradiographs were scanned using an Ultrascan XL laser densitometer (LKB Produckter, Uppsala, Sweden) and software package (2400 Gelscan XL; LKB Produckter). The scanning values of ANF and BNP mRNAs were normalized by the relative abundance of $28 \mathrm{~S}$ ribosomal RNA or phosphoglycerate kinase (PGK) mRNA as internal controls to correct for differences in the amount of RNA applied and transfer efficiency.

\section{Assay methods}

Concentrations of urinary sodium and potassium were determined in an automatic analyzer (model CX3; Beckman Instruments, Inc., Brea, CA). Urinary cGMP concentrations were determined with a commercially available RIA kit (Dupont-NEN, Boston, MA). Plasma and cardiac tissue concentrations of immunoreactive (ir) ANF and BNP were determined by RIA using anti-rat $\mathrm{ANF}_{99-126}$ and anti-rat $\mathrm{BNP}_{64-95}$ serum, respectively, from Peninsula Laboratories, Inc. (Belmont, CA) (38). The antibodies used showed less than $0.01 \%$ crossreactivity between $\mathrm{ANF}$ and BNP.

\section{Statistical analysis}

The data were analyzed using ANOVA for repeated measures followed by Fisher's least significant difference test when appropriate. The significance of the difference between pairs of means was determined using an unpaired Student's $t$ test. All results were expressed as mean \pm SEM and a level of $P<0.05$ was considered significant. 

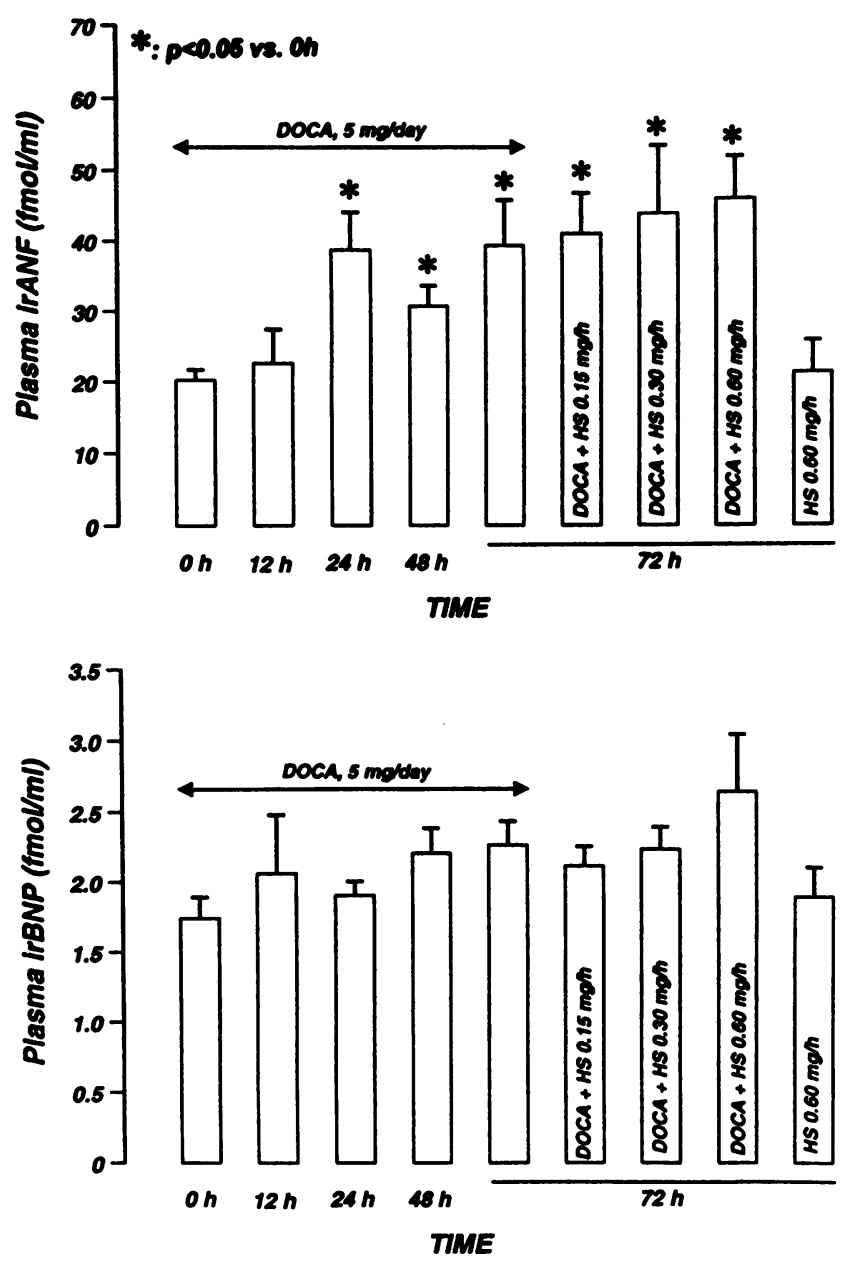

Figure 1. irANF (top) and irBNP (bottom) in plasma at 0, 12, 24, 48, and $72 \mathrm{~h}$ after administration of DOCA with or without HS, or HS alone ( $n=5$ for each group).

\section{Results}

DOCA animals. Plasma irANF in DOCA animals significantly rose from $20 \pm 2 \mathrm{fmol} / \mathrm{ml}$ at $0 \mathrm{~h}$ to $39 \pm 5 \mathrm{fmol} / \mathrm{ml}$ at $24 \mathrm{~h}(P$ $<0.05$ ), and remained significantly elevated at both 48 and 72 h (each $P<0.05$, Fig. 1). Atrial irANF content significantly decreased below control values $(0 \mathrm{~h})$ at $24 \mathrm{~h}(P<0.05)$ and further decreased at 48 and $72 \mathrm{~h}(P<0.05$ and $P<0.01$, respectively; Fig. 2). Northern blot analysis with the rat ANF cDNA probe identified a single $0.9 \mathrm{~kb}$ mRNA species in the atria (Fig. 3) and ventricle (Fig. 4). The levels of atrial ANF mRNA began to rise at $24 \mathrm{~h}$ and reached statistically higher levels at $72 \mathrm{~h}$ (2.4-fold increase at $0 \mathrm{~h}, P<0.05$; Figs. 3 and $5)$. In contrast to ANF, irBNP levels did not change in plasma or in atria (Figs. 1 and 2), although atrial BNP mRNA levels increased significantly at $72 \mathrm{~h}(1.9$-fold increase, $P<0.05$; Figs. 3 and 5). There were no significant changes in ventricular ANF and BNP peptide or specific mRNA levels over the $72 \mathrm{~h}$ (Figs. 2, 4, and 5).

Table I and Fig. 6 summarize urinary parameters for DOCAtreated animals. Urinary volume (UV) in DOCA animals was increased over the basal value at 24,48 , and $72 \mathrm{~h}$. The values for the last two time points were statistically significant when compared to basal value. In the same samples, urinary potassium excretion $\left(U_{K} V\right)$ increased significantly from the basal value on the first day and remained elevated during the second and third days, thus demonstrating the persistence of the mineralocorticoid action of DOCA. Urinary sodium excretion $\left(\mathrm{U}_{\mathrm{Na}} \mathrm{V}\right)$ was decreased markedly as compared to the basal value in the first day, but it returned towards basal levels on the second and subsequent days $(1.4 \pm 0.2$ and $1.8 \pm 0.3 \mu \mathrm{mol} / \mathrm{g}$ body weight, respectively, Table I, Fig. 6), indicating escape from the sodium-retaining effects of DOCA. Urinary cGMP excretion $\left(\mathrm{U}_{\mathrm{cGMP}} \mathrm{V}\right)$ was significantly increased over the basal value during the first, second, and third days.

DOCA + HS animals. Plasma irANF in DOCA + HS animals at $72 \mathrm{~h}$ tended to be higher compared with those of DOCA animals. Only the rats with DOCA $+0.6 \mathrm{mg} / \mathrm{h} \mathrm{HS}$ at $72 \mathrm{~h}$ had a higher plasma irBNP compared with those at $0 \mathrm{~h}$, but the differences were not statistically significant. Atrial irANF in DOCA + HS animals decreased more markedly, while there was no change in atrial irBNP, as compared to those at $0 \mathrm{~h}$ (Fig. 2). Atrial ANF and BNP mRNA levels in DOCA + HS animals tended to be higher at $72 \mathrm{~h}$ than those in animals treated with DOCA alone. However, ventricular ANF and BNP peptide and mRNA levels in DOCA + HS animals were comparable to those of $0 \mathrm{~h}$.

Urinary parameters in DOCA + HS animals are summarized in Table I and Fig. 6. UV was significantly increased in the second and third days in rats treated with $0.15 \mathrm{mg} / \mathrm{h} \mathrm{HS}$, but it did not differ in rats treated with 0.3 or $0.6 \mathrm{mg} / \mathrm{h}$ HS as compared with their respective basal values. $U_{K} V$ was increased significantly over basal values in the second and third days, but this increase was not dependent on the HS dose. $U_{\mathrm{Na}} \mathrm{V}$ and $\mathrm{U}_{\mathrm{cGMP}} \mathrm{V}$ decreased significantly and in a dose-dependent manner in the second and third days with 0.3 or $0.6 \mathrm{mg} / \mathrm{h} \mathrm{HS}$, but not with $0.15 \mathrm{mg} / \mathrm{h}$ HS as compared to DOCA group of the same day. There was no $\mathrm{U}_{\mathrm{cGMP}} \mathrm{V}$ elevation in rats treated with DOCA $+0.6 \mathrm{mg} / \mathrm{h}$ HS over the $72-\mathrm{h}$ observation period.

$H S$ animals. No changes were detected in ANF or BNP plasma levels, or in peptide content or mRNA levels, in atria or ventricles at $72 \mathrm{~h}$ as compared to those at $0 \mathrm{~h}$. In animals treated with HS alone, no changes were observed in any of the urinary parameters over the entire 72 -h observation period.

\section{Discussion}

The polypeptide cardiac hormones ANF and BNP share several biological properties including a powerful natriuretic action. For this reason, the participation of these peptides has been conjectured in the mineralocorticoid escape phenomenon. This view is supported by previous investigations in animals showing a rise in plasma ANF before or coincidental with escape (15, 21-24).

The mechanism underlying plasma ANF elevation during DOCA administration is unknown. Since chronic mineralocorticoid excess is characterized by extracellular fluid expansion and plasma ANF levels increase in parallel with central venous pressure elevation following DOCA administration (24), increased ANF release from atria may be considered secondary to a rise in intravascular volume, central venous pressure, and atrial stretch. However, simple atrial stretch does not explain the sustained increase in ANF release. We have found recently that stretch-mediated ANF release is short lived and associated with a rapid depletion of a pool of newly synthesized ANF. 

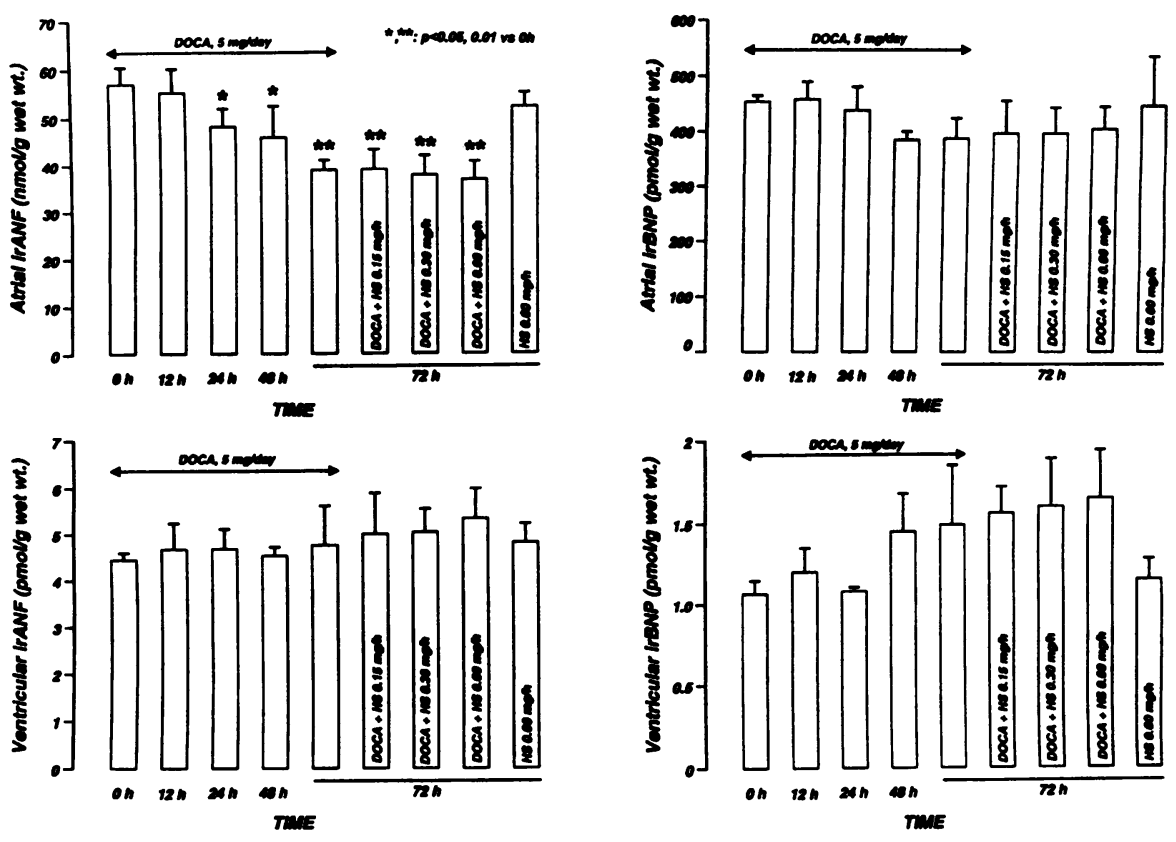

Figure 2. irANF (left) and irBNP (right) in atria (top) and ventricles (bottom) at 0,12 , 24,48 , and $72 \mathrm{~h}$ after administration of DOCA with or without HS, or HS alone ( $n$ $=5$ for each group).

This occurs without any significant effect on the levels of stored peptide (40) or on steady state mRNA levels (39). The present investigation shows that atrial ANF content decreased significantly at $24 \mathrm{~h}$ after the first 5-mg DOCA injection, corresponding to the initiation of plasma ANF elevation. Thus, it is likely that previously stored ANF contributes to the response to DOCA administration. Whether DOCA directly stimulates ANF secretion from the storage pool in atrial cardiocytes has not been determined.

Limited data are available on the time course changes in cardiac natriuretic peptide synthesis during mineralocorticoid escape. Ballermann et al. (21) reported that plasma ANF concentration and atrial mRNA changed in parallel as early as 12 $h$ after 10-mg DOCA injection in rats. In the present work, in which a smaller DOCA dose was used, atrial ANF mRNA levels increased comparatively more gradually and were significantly different from controls only at $72 \mathrm{~h}$. Assuming that ANF mRNA turnover rates are similar between our treated and control animals, the data suggest that atrial ANF gene transcription enhancement is secondarily rather than primarily related to DOCA treatment. This view is further substantiated by the fact that DOCA does not directly stimulate ANF gene transcription in cultured atrial cardiocytes (41). Moreover, no specific receptors for mineralocorticoid exist in the cardiac cytosol (42).

The effects of mineralocorticoid on cardiac release and synthesis of BNP have not been as extensively investigated as those on ANF. The unchanged levels of circulating BNP found in this work does not support a substantial role for this hormone in DOCA escape. However, we found that atrial BNP stores, in a fashion similar to ANF stores, tended to decrease and that BNP mRNA levels, as for ANF mRNA levels, significantly increased after $72 \mathrm{~h}$ following DOCA injection. These changes tended to be more pronounced after treatment with HS, possibly reflecting a more pronounced extracellular volume expansion due to a larger suppressive effect on the diuretic and natriuretic activities of natriuretic peptides. These results further suggest that stimulation of BNP secretion and gene transcription in atria are secondary to hemodynamic overload, as indicated for ANF. BNP is co-stored with ANF in a subset of atrial secretory granules (43) and the release mechanisms seem to be, at least in part, via a regulated pathway because atrial BNP secretion is increased in response to appropriate secretagogues such as endothelin-1 or phorbol ester $(39,44)$. Overall, these findings indicate that atrial BNP can respond to atrial hemodynamic
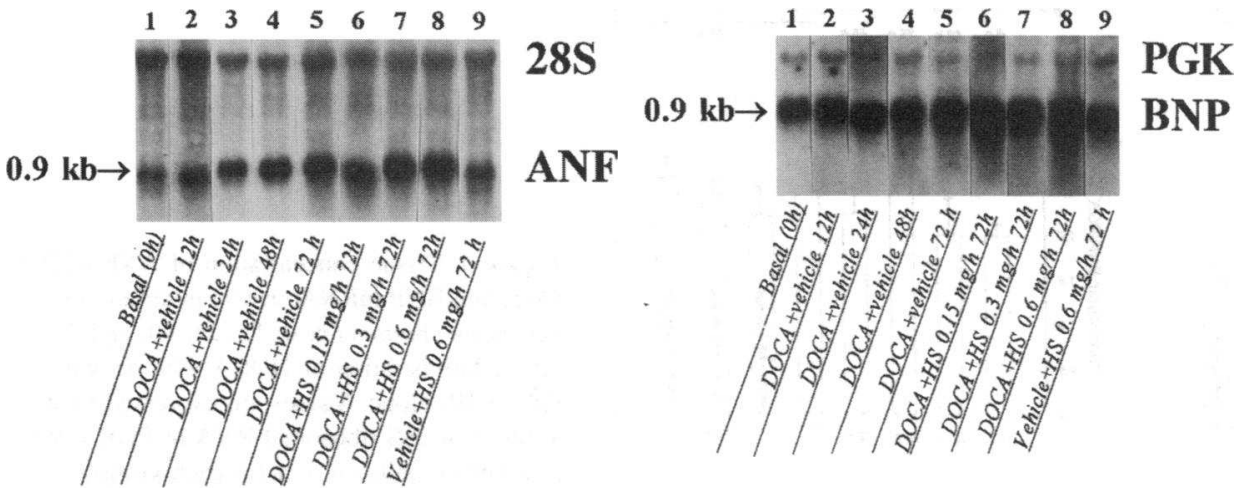

Figure 3. Northern blot analysis of ANF and BNP mRNAs from atria. 28S ribosomal RNA and phosphoglycerate kinase (PGK) mRNA were used as an internal control. Each lane contained $10 \mu \mathrm{g}$ total RNA. 

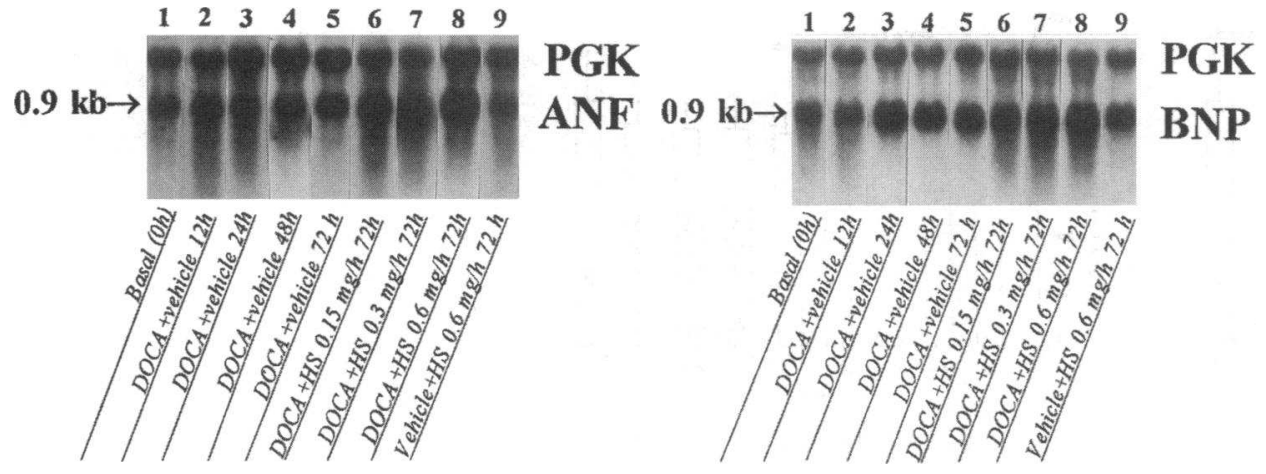

Figure 4. Northern blot analysis of ANF and BNP mRNAs from ventricle. Values were normalized to PGK mRNA. Each lane contained $20 \mu \mathrm{g}$ total RNA.

overload induced by DOCA administration. However, the increase in plasma BNP was comparatively small and, unlike ANF, did not reach statistically significant levels over the 72$h$ period of DOCA administration. The distinctive responsive patterns of plasma ANF and BNP during DOCA administration may reflect differences in their primary site of expression within the heart or differences in pathways for induction of stimulated secretion. Recent evidence suggests that BNP is mainly synthesized and secreted by ventricular cardiocytes in both physiological and pathological conditions $(45,46)$. The plasma BNP response is reported to be relatively more pronounced than ANF in patients with essential hypertension in proportion to left ventricular hypertrophy (47) and in patients with congestive heart failure in proportion to ventricular volume overload (45). These changes in BNP release over a chronic period of demand are in contrast with changes induced by acute maneuvers such as changes in posture or acute intravenous saline infusion, both of which alter atrial pressure and plasma ANF while plasma BNP is unaffected $(48,49)$. These results suggest the plasma BNP levels reflect the secretion from ventricle and thus, not atrial but ventricular load or wall tension may be more significant in influencing plasma BNP levels. In the present study we did not observe an increase in ventricular BNP peptide and mRNA levels during DOCA treatment suggesting that ventricular BNP biosynthesis was not significantly stimulated. Absence of ventricular BNP activation may be explained by the insignificant change in arterial blood pressure, and therefore, of left ventricular wall tension, during mineralocorticoid escape (12-14). It was noted in the present work that the highest plasma and ventricular BNP and specific mRNA levels were observed in rats treated with DOCA together with $0.6 \mathrm{mg} / \mathrm{h}$ HS. Hirata et al. (50) reported that bolus injection of $8 \mathrm{mg} / \mathrm{kg}$ HS significantly elevated blood pressure by $8 \%$ together with a $14 \%$ increase in systemic vascular resistance in DOCA-salt rats. Therefore in our studies, the volume overload and increase in arterial pressure following chronic treatment with the highest dose of HS might have enhanced left ventricular load and wall tension and thus activated BNP synthesis and secretion from the ventricles. While this might have happened, the changes observed were not statistically significant compared with basal ( 0 h) values. This is in accordance with previous findings showing that plasma BNP levels increase only after the establishment of hypertension in spontaneously hypertensive rats (51) or DOCAsalt hypertensive rats (52) and suggest that more sustained or stronger hemodynamic stimuli may be needed to activate ventricular BNP.

Plasma ANF levels increased to approximately twice the
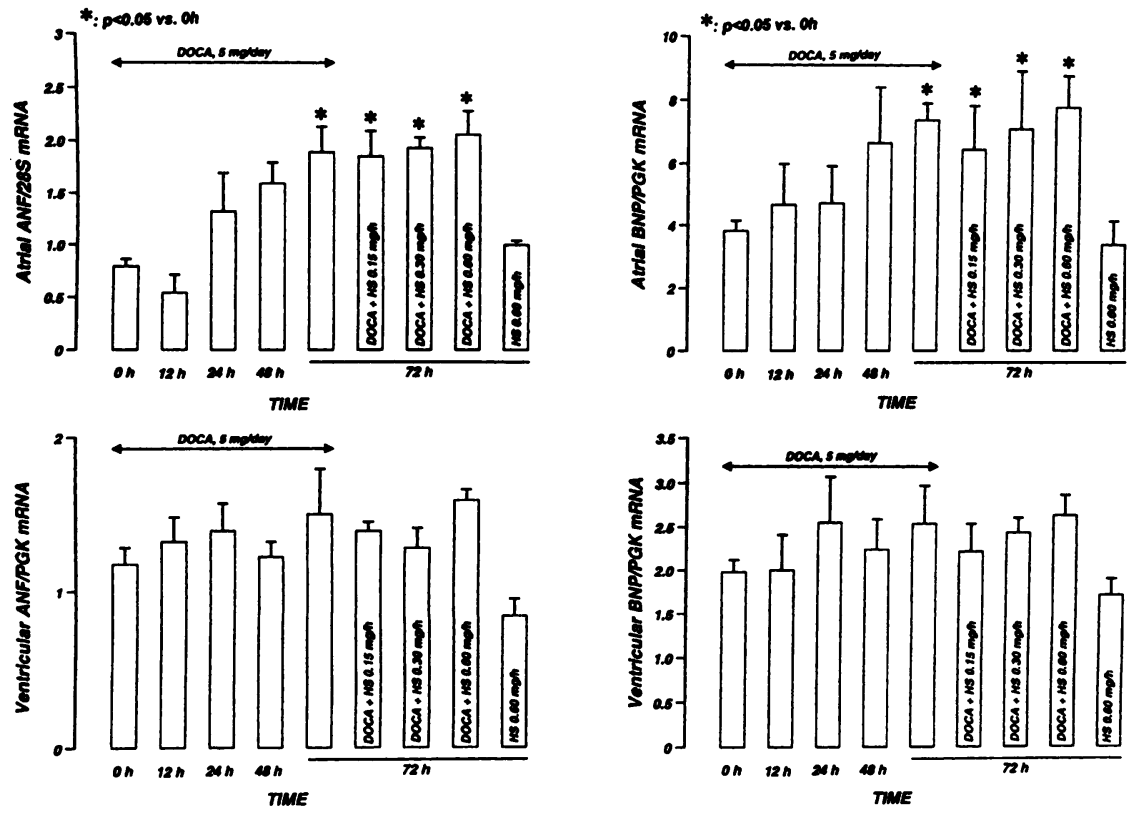

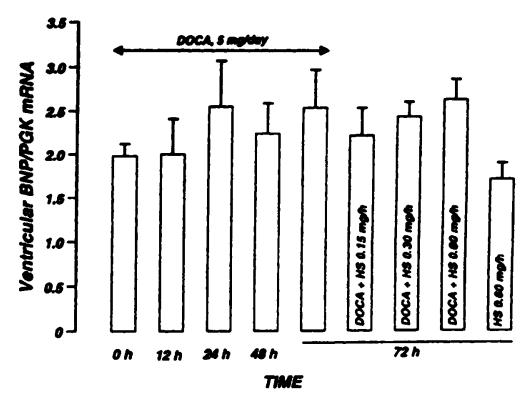

Figure 5. Tissue concentration of ANF mRNA (left) and BNP mRNA (right) in atria (top) and ventricles (bottom) at $0,12,24,48$, and $72 \mathrm{~h}$ after administration of DOCA with or without HS, or HS alone. Values are expressed relative to those of $28 \mathrm{~S}$ ribosomal RNA or PGK mRNA in arbitrary units ( $n=5$ for each group). 
Table I. Summary Urinary Data for Control and Test Animals during Mineralocorticoid Escape

\begin{tabular}{|c|c|c|c|c|c|}
\hline Treatment & $\begin{array}{l}\text { Urinary } \\
\text { parameter }\end{array}$ & Basal & Day 1 & Day 2 & Day 3 \\
\hline \multirow[t]{4}{*}{ DOCA alone } & UV & $35 \pm 2$ & $38 \pm 5$ & $41 \pm 5^{*}$ & $43 \pm 4 *$ \\
\hline & $\mathbf{U}_{\mathbf{K}} \mathbf{V}$ & $6.3 \pm 0.4$ & $7.6 \pm 0.6^{*}$ & $8.1 \pm 0.5^{* *}$ & $8.8 \pm 0.7 * *$ \\
\hline & $\mathrm{U}_{\mathrm{Na}} \mathrm{V}$ & $1.8 \pm 0.1$ & $0.4 \pm 0.2 * *$ & $1.4 \pm 0.2$ & $1.8 \pm 0.3$ \\
\hline & $\mathrm{U}_{\mathrm{cGMP}} \mathrm{V}$ & $124 \pm 12$ & $190 \pm 24^{* *}$ & $213 \pm 41 * *$ & $209 \pm 66 * *$ \\
\hline \multirow{4}{*}{$\mathrm{DOCA}+\mathrm{HS}(0.15 \mathrm{mg} / \mathrm{h})$} & UV & $34 \pm 3$ & $31 \pm 3$ & $40 \pm 3^{*}$ & $39 \pm 4 *$ \\
\hline & $\mathrm{U}_{\mathrm{K}} \mathrm{V}$ & $6.7 \pm 0.3$ & $7.1 \pm 0.2$ & $8.1 \pm 0.3 * *$ & $8.2 \pm 0.5^{* *}$ \\
\hline & $\mathrm{U}_{\mathrm{Na}} \mathrm{V}$ & $1.8 \pm 0.2$ & $0.2 \pm 0.04^{* *}$ & $0.7 \pm 0.2^{* * \dagger}$ & $1.3 \pm 0.1$ \\
\hline & $\mathrm{U}_{\mathrm{CGMP}} \mathrm{V}$ & $121 \pm 17$ & $134 \pm 16$ & $169 \pm 21 *$ & $181 \pm 19^{*}$ \\
\hline \multirow[t]{4}{*}{ DOCA + HS $(0.3 \mathrm{mg} / \mathrm{h})$} & UV & $32 \pm 2$ & $35 \pm 6$ & $36 \pm 2$ & $36 \pm 2$ \\
\hline & $\mathrm{U}_{\mathrm{k}} \mathrm{V}$ & $6.2 \pm 0.1$ & $6.8 \pm 0.7$ & $7.6 \pm 0.5^{*}$ & $7.6 \pm 0.4^{*}$ \\
\hline & $\mathrm{U}_{\mathrm{Na}} \mathrm{V}$ & $1.8 \pm 0.1$ & $0.2 \pm 0.1 * *$ & $0.4 \pm 0.2^{* *+\dagger}$ & $1.1 \pm 0.1$ \\
\hline & $\mathrm{U}_{\mathrm{cGMP}} \mathrm{V}$ & $117 \pm 11$ & $135 \pm 32$ & $149 \pm 10^{\dagger}$ & $154 \pm 10^{\dagger}$ \\
\hline \multirow[t]{4}{*}{ DOCA + HS $(0.6 \mathrm{mg} / \mathrm{h})$} & UV & $38 \pm 3$ & $34 \pm 4$ & $39 \pm 4$ & $38 \pm 4$ \\
\hline & $\mathrm{U}_{\mathbf{K}} \mathbf{V}$ & $6.9 \pm 0.3$ & $7.1 \pm 0.3$ & $8.1 \pm 0.3^{*}$ & $8.4 \pm 0.8^{*}$ \\
\hline & $\mathrm{U}_{\mathrm{Na}} \mathrm{V}$ & $1.8 \pm 0.1$ & $0.2 \pm 0.1 * *$ & $0.4 \pm 0.2 * * \dagger \dagger$ & $0.5 \pm 0.1^{* * \dagger \dagger}$ \\
\hline & $\mathrm{U}_{\mathrm{cGMP}} \mathrm{V}$ & $123 \pm 12$ & $116 \pm 10^{\dagger}$ & $129 \pm 27^{+}$ & $117 \pm 41^{\dagger}$ \\
\hline \multirow[t]{4}{*}{ HS alone } & UV & $37 \pm 3$ & $37 \pm 2$ & $40 \pm 5$ & $42 \pm 6$ \\
\hline & $\mathrm{U}_{\mathrm{K}} \mathrm{V}$ & $6.6 \pm 0.2$ & $6.8 \pm 0.3^{\dagger}$ & $6.5 \pm 0.6^{\dagger \dagger}$ & $6.3 \pm 0.2^{\dagger+}$ \\
\hline & $\mathrm{U}_{\mathrm{Na}} \mathrm{V}$ & $1.9 \pm 0.1$ & $1.8 \pm 0.3^{\dagger \dagger}$ & $1.9 \pm 0.1$ & $1.8 \pm 0.2$ \\
\hline & $\mathrm{U}_{\mathrm{CGMP}} \mathrm{V}$ & $115 \pm 16$ & $96 \pm 10^{\dagger}$ & $122 \pm 7^{\dagger \dagger}$ & $116 \pm 29^{\dagger}$ \\
\hline
\end{tabular}

The highlighted values for animals treated with DOCA alone show the escape from the mineralocorticoid effect evident in day 1 . Corresponding values are highlighted for animals treated with DOCA + increasing doses of HS or for animals treated with HS alone. Units are UV, $\mu \mathrm{l} / \mathrm{g}$ body weight; $\mathrm{U}_{\mathrm{Na}} \mathrm{V}$ and $\mathrm{U}_{\mathrm{K}} \mathrm{V}, \mu \mathrm{mol} / \mathrm{g}$ body weight; and $\mathrm{U}_{\mathrm{cGMP}} \mathrm{V}, \mathrm{pmol} / \mathrm{g}$ body weight. Values are mean $\pm \mathrm{SEM}$ of five determinations. $* P<0.05, * * P$ $<0.01$ vs. basal value; ${ }^{\dagger} P<0.05,{ }^{+\dagger} P<0.01$ vs. DOCA alone.

basal levels $24 \mathrm{~h}$ after the first injection of DOCA. With the sampling scheme used, it appears as if the increase in plasma ANF and return of $U_{\mathrm{Na}} \mathrm{V}$ to basal levels are coincidental, but it is possible that the rise in plasma ANF may have preceded the escape as found previously $(13,15,21,25)$. The increase in plasma ANF observed in the present study is similar to levels achieved by small dose ANF infusion, by inhibiting neutral endopeptidase with phosphoramidon or by blockade of the ANF clearance receptor; these are procedures that lead to an effective natriuresis $(53,54)$. Further, an investigation in humans following $9 \boldsymbol{\alpha}$-fludrocortisone acetate administration (13) demonstrated a critical relationship between plasma ANF and sodium balance whereby an abrupt increase in plasma ANF levels occurs when the cumulative sodium balance exceeds $220 \mathrm{nmol}$. These observations suggest the possible role of ANF in DOCA escape. In contrast, Greenwald et al. (33) could not ascribe a role for ANF in mineralocorticoid escape because passive immunization with anti-ANF antiserum did not influence escape. On the other hand, Zeng et al. (22) reported that antiserum against ANF diminishes the natriuretic response during mineralocorticoid escape. Whether these conflicting results are due to differences in the antibody used or other differences in experimental parameters is difficult to ascertain because urinary cGMP was not measured in either of these two investigations.

It has been previously reported that $\sim 75 \%$ of intravenously administered cGMP is rapidly eliminated from the circulation by extrarenal clearance (55) indicating that changes in plasma cGMP levels do not largely determine $U_{\text {cGMP }} V$. Significant doseand time-dependent increases in cGMP renal production are induced by in vivo administration of ANF (56) and, therefore, the increased urinary cGMP excretion becomes a marker of ANF action on the kidney. The availability of HS, a nonpeptide antagonist specific for guanylate cyclase-coupled natriuretic peptide receptors isolated from microbial cultures (34), has made it possible to investigate cGMP-mediated actions of natriuretic peptides. The present study is the first to take advantage of HS to examine the effects of chronic natriuretic peptide guanylate cyclase receptor blockade and to do so in conscious animals. Among the most salient observations of the present work is the fact that HS alone did not influence ANF or BNP plasma levels, cardiac tissue content, or specific mRNA levels, suggesting that this compound is essentially devoid of the agonistic activities towards hormone secretion and synthesis that is often seen with peptide antagonists.

The time course of changes in plasma ANF levels in the present work closely paralleled the increase in $\mathrm{U}_{\mathrm{cGMP}} \mathrm{V}$. Further, this increase was reduced by HS treatment in a dose-dependent manner, suggesting that $U_{\mathrm{cGMP}} V$ is associated with plasma ANF. Although some reports suggest that kidney-derived peptide could potentially contribute to natriuresis in a paracrine fashion, the abundance of their gene transcripts in the kidney is exceedingly low compared with those in cardiac atria, and preliminary data in this laboratory using RT-PCR amplification of ANF mRNA show that the transcript is not augmented in DOCAtreated rats (Yokota N., and A. J. de Bold, unpublished observations). Therefore, the increase in $U_{\text {cGMP }} V$ observed during DOCA escape may hence be viewed as the result of increased renal cGMP production induced by increased plasma-borne ANF binding to guanylate cyclase-coupled receptors. Lafferty et al. (54) reported that a threefold increase in plasma ANF 

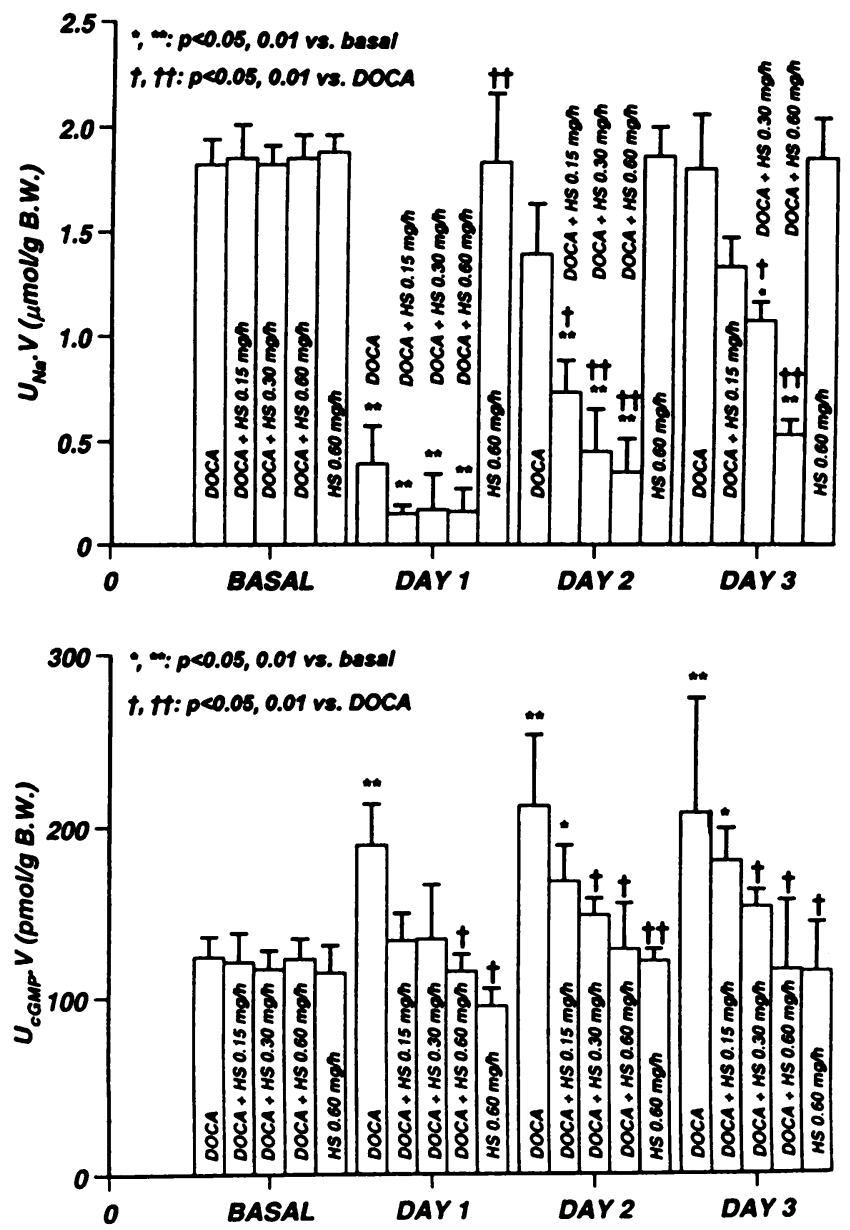

Figure 6. Urinary sodium excretion $\left(\mathrm{U}_{\mathrm{Na}} \mathrm{V}\right.$, top $)$ and urinary cGMP excretion $\left(\mathrm{U}_{\mathrm{CGMP}} \mathrm{V}\right.$, bottom $)$ following administration of DOCA with or without HS, or HS alone ( $n=5$ for each group).

induced by phosphoramidon infusion produced a fivefold increase in $\mathrm{U}_{\mathrm{cGMP}} \mathrm{V}$ as well as five times increase of $\mathrm{U}_{\mathrm{Na}} \mathrm{V}$ in rats. Hirata et al. (57) reported that $\mathrm{U}_{\mathrm{Na}} \mathrm{V}$ and $\mathrm{U}_{\mathrm{cGMP}} \mathrm{V}$ were dosedependently increased by pretreatment with thiorphan in association with a prolonged ANF half-life in the rat kidney. Taken together, the significant, dose-dependent impairment of escape by HS, which is shown in the present work, strongly suggests that ANF-induced increase in renal cGMP production plays a role in mediating escape.

Several intrarenal sites responsible for mineralocorticoid escape have been postulated. Mineralocorticoids specifically bind to the principal cell population of the cortical collecting duct $(1,58)$ and powerfully increases $\mathrm{Na}^{+}-\mathrm{K}^{+}$-ATPase activity $(59)$ before and after DOCA-treatment (1), showing that the nephron site responsible for escape is different from the mineralocorticoid site of action. The mineralocorticoid action causes an increase in extracellular fluid leading to an increase in GFR and filtered sodium load. In addition, the increase in renal perfusion pressure and decrease in renal sympathetic nerve activity lead to decreased renin release, thereby decreasing the generation of angiotensin II and sodium reabsorption by the proximal tubule $(3,8,14,60)$. The increase in vasa recta and interstitial hydrostatic pressure due to volume expansion reduce collecting tubular sodium reabsorption by decreasing the hydraulic gradient
$(5,61)$. ANF should be expected to contribute to these mechanisms by virtue of its property of increasing GFR and directly inhibiting renin release $(62,63)$, as well as increasing vasa recta blood flow as a consequence of renal vasodilation (64). Lastly, ANF binds to the inner medullary collecting duct cells and powerfully stimulates intracellular cGMP production and blocks amiloride-sensitive $\mathrm{Na}^{+}$channels (65-69). Overall, the data suggest that ANF contributes to mineralocorticoid escape through combined renal hemodynamic and tubular effects. It is not known at present whether the number and/or affinity of renal natriuretic peptide receptor are increased during mineralocorticoid escape. Studies comparing the effects of exogenously administered ANF before and after fludrocortisone escape in humans (13) showed that enhanced natriuretic effects were observed after escape with a greater suppression of proximal and distal tubular sodium reabsorption. These authors suggest that mineralocorticoid escape is accompanied by a potentiation of the natriuretic effect of ANF.

In summary, we found that plasma ANF increases in association with increases in $\mathrm{UV}, \mathrm{U}_{\mathrm{Na}} \mathrm{V}$, and $\mathrm{U}_{\mathrm{CGMP}} \mathrm{V}$ following sodium retention induced by DOCA excess. The increase in plasma ANF reflects increases in secretion and synthesis of ANF from atria that are probably secondary to central volume overload. Atrial BNP also seems to be stimulated but plasma BNP levels remained comparatively unaffected probably because of a lack of ventricular stimulation. Blockade of guanylate cyclase-mediated natriuretic peptides activities with HS significantly and dose-dependently suppressed the increase in $\mathrm{UV}, \mathrm{U}_{\mathrm{Na}} \mathrm{V}$, and $\mathrm{U}_{\mathrm{cGMP}} \mathrm{V}$ observed during DOCA escape in conscious rats. These results provide new evidence that cardiac ANF plays a significant role in mediating mineralocorticoid escape and that this mediation takes place through a guanylate cyclase-dependent pathway. However, noteworthy is the fact that the highest dose of $\mathrm{HS}$ blocked the increase in $\mathrm{U}_{\mathrm{CGMP}} \mathrm{V}$ completely but $\mathrm{U}_{\mathrm{Na}} \mathrm{V}$ in the second and third days tended to increase. This slight but definite increase raises the possibility that cGMP-independent pathways may come eventually into play to restore sodium balance. Whether these pathways lead to complete restoration of sodium balance even with natriuretic peptide guanylate cyclase-coupled receptor blockade remains to be determined.

\section{Acknowledgments}

We thank Dr. Y. Matsuda, Tokyo Research Laboratories Kyowa Hakko Kyogo Co. Ltd. (Tokyo, Japan) for kindly providing HS-142-1, Dr. K. R. Chien (University of California at San Diego) for the generous gift of the $28 \mathrm{~S}$ ribosomal RNA cDNA, and Dr. P. H. Boer (University of Ottawa Heart Institute, Ottawa, Ontario, Canada) for providing the PGK cDNA. We also acknowledge Ms. Michelle Stevenson and Ms. Lorraine Pawson for their excellent technical assistance.

This work was supported by the Medical Research Council of Canada, and the Heart and Stroke Foundation of Ontario.

\section{References}

1. O'Neil, R. G. and S. I. Helman. 1977. Transport characteristics of renal collecting tubules: influences of DOCA and diet. Am. J. Physiol. 232:F544-F558.

2. Higgins, J. T., Jr. 1970. Escape from sodium retaining effects of deoxycorticosterone in hypotensive and hypertensive dogs. Proc. Soc. Exp. Biol. Med. 134:768-772.

3. Schnermann, J. M., M. Hermle, E. Schmidmeier, and H. Dalheim. 1975. Impaired potency of feedback regulation of glomerular filtration rate in DOCA escaped rats. Pflueg. Arch. Eur. J. Physiol. 358:325-338.

4. Hall, J. E., J. P. Granger, M. J. Smith, and A. J. Premen. 1984. Role of 
renal hemodynamics and arterial pressure in aldosterone "escape". Hypertension (Dallas). 6(Suppl. 1):183-192.

5. Burnett, J. C., Jr., J. A. Haas, and M. S. Larson. 1985. Renal interstitial pressure in mineralocorticoid escape. Am. J. Physiol. 249:F396-F399.

6. Overlack, A., E. Backer-Kreutz, C. Ressel, H. M. Muller, R. Kolloch, and K. O. Stumpe. 1986. Mineralocorticoid escape during kallikrein inhibition. Clin. Sci. (Lond.). 70:13-17.

7. Dürr, J., L. Favre, R. Gaillard, A. M. Riondel, and M. B. Vallotton. 1982. Mineralocorticoid escape in man: role of renal prostaglandins. Acta Endocrinol. 99:474-480.

8. Biollaz, J., J. Dürr, H. R. Brunner, M. Porchet, and H. Gavras. 1982. Escape from mineralocorticoids excess: the role of angiotensin II. J. Clin. Endocrinol. \& Metab. 54:1187-1193.

9. Romero, J. C., F. G. Knox, T. J. Opgenorth, J. P. Granger, and J. A. Keiser. 1985. Contribution of sympathetic neural reflexes to mineralocorticoid escape. Fed. Proc. 44:2382-2387.

10. Düsing, R., R. Wilkie, A. Körber, D. Klingmuller, and H. J. Kramer. 1981. Inner medullary osmolality and sodium concentrations are decreased in rats during escape from DOCA-induced salt retention. Clin. Sci. (Lond.). 60:467469.

11. Reinhardt, H. W., W. Boemke, Ü. Palm, and G. Kaczmarczyk. 1990. What causes escape from sodium retaining hormones? Acta Physiol. Scand. Suppl. 591:12-17.

12. Zimmerman, R. S., B. S. Edwards, T. R. Schwab, D. M. Heublein, and J. C. Burnett, Jr. 1987. Atrial natriuretic peptide during mineralocorticoid escape in the human. J. Clin. Endocrinol. \& Metab. 64:624-627.

13. Miyamori, I., M. Ikeda, T. Matsubara, S. Okamoto, H. Koshida, T. Morise, and R. Takeda. 1987. Human atrial natriuretic polypeptide during escape from mineralocorticoid excess in man. Clin. Sci. (Lond.). 73:431-436.

14. Gonzalez-Campoy, J. M., J. Kachelski, J. C. Burnett, Jr., J. C. Romero, J. P. Granger, and F. G. Knox. 1989. Proximal tubule response in aldosterone escape. Am. J. Physiol. 256:R86-R90.

15. Granger, J. P., J. C. Burnett, Jr., J. C. Romero, T. J. Opgenorth, J. Salazar, and M. Joyce. 1987. Elevated levels of atrial natriuretic peptide during aldosterone escape. Am. J. Physiol. 252:R878-R882.

16. Dickstein, G. M., J. F. Woodson, N. E. Lamb, C. E. Rose, Jr., M. J. Peach, and R. M. Carey. 1985. Escape from the sodium-retaining action of intrarenal angiotensin II and III in the concious dog. Endocrinology. 117:2160-2169.

17. de Bold, A. J., H. B. Borenstein, A. T. Veress, and H. Sonnenberg. 1981. A rapid and potent natriuretic response to intravenous injection of atrial myocardial extracts in rats. Life Sci. 28:89-94.

18. de Bold, A. J. 1985. Atrial natriuretic factor: a hormone produced by the heart. Science (Wash. DC). 230:767-770.

19. Sudoh, T., K. Kangawa, N. Minamino, and H. Matsuo. 1988. A new natriuretic peptide in porcine brain. Nature (Lond.). 332:78-81.

20. Sudoh, T., N. Minamino, K. Kangawa, and H. Matsuo. 1990. C-type natriuretic peptide (CNP): a new member of natriuretic peptide family identified in porcine brain. Biochem. Biophys. Res. Commun. 168:863-870.

21. Ballermann, B. J., K. D. Bloch, J. G. Seidman, and B. M. Brenner. 1986. Atrial natriuretic peptide transcription, secretion, and glomerular receptor activity during mineralocorticoid escape in the rat. J. Clin. Invest. 78:840-843.

22. Zeng, Z. P., M. Naruse, K. Naruse, Y. Kato, Y. F. Shi, H. Demura, and K. Shizume. 1991. Antiserum against homologous atrial natriuretic peptide diminishes the natriuretic response during mineralocorticoid escape in rats. Endocrinology. 128:226-230.

23. Metzler, C. H., D. G. Gardner, L. C. Keil, J. D. Baxter, and D. J. Ramsay. 1987. Increased synthesis and release of atrial peptide during DOCA escape in conscious dogs. Am. J. Physiol. 252:R188-R192.

24. Grekin, R. J., W. D. Ling, Y. Shenker, and D. F. Bohr. 1986. Immunoreactive atrial natriuretic hormone levels increase in deoxycorticosterone-treated pigs. Hypertension. (Dallas). 8(Suppl. 2):II16-II20.

25. Cappuccio, F. P., N. D. Markandu, M. G. Buckley, G. A. Sagnella, A. C. Shore, and G. A. MacGregor. 1987. Changes in the plasma levels of atrial natriuretic peptides during mineralocorticoid escape in man. Clin. Sci. (Lond.). 72:531-539.

26. Tunny, T. J., B. A. Higgins, and R. D. Gordon. 1986. Plasma levels of atrial natriuretic peptide in man in primary aldosteronism, in Gordon's syndrome and in Bartter's syndrome. Clin. Exp. Pharmacol. Physiol. 13:341-345.

27. Holmes, S. J., E. A. Espiner, A. M. Richards, T. G. Yandle, and C. Frampton. 1993. Renal, endocrine, and hemodynamic effects of human brain natriuretic peptide in normal man. J. Clin. Endocrinol. \& Metab. 76:91-96.

28. Schulz, S., S. Singh, R. A. Bellet, G. Singh, D. J. Tubb, H. Chin, and D. L. Garbers. 1989. The primary structure of a plasma membrane guanylate cyclase demonstrates diversity within this new receptor family. Cell. 58:11551162.

29. Chang, M. S., D. G. Lowe, M. Lewis, R. Hellmiss, E. Chen, and D. V. Goeddel. 1989. Differential activation by atrial and brain natriuretic peptides of two different receptor guanylate cyclases. Nature (Lond.). 341:68-72.

30. Terada, Y., T. Moriyama, B. M. Martin, M. A. Knepper, and A. Garcia-
Perez. 1991. RT-PCR microlocalization of mRNA for guanylyl cyclase-coupled ANF receptor in rat kidney. Am. J. Physiol. 261:F1080-F1087.

31. Koller, K. J., D. G. Lowe, G. L. Bennett, N. Minamino, K. Kangawa, H. Matsuo, and D. V. Goeddel. 1991. Selective activation of the B natriuretic peptide receptor by C-type natriuretic peptide (CNP). Science (Wash. DC). 252:120123.

32. Suga, S., K. Nakao, K. Hosoda, M. Mukoyama, Y. Ogawa, G. Shirakami, H. Arai, Y. Saito, Y. Kambayashi, K. Inouye, et al. 1992. Receptor selectivity of natriuretic peptide family, atrial natriuretic peptide, brain natriuretic peptide, and C-type natriuretic peptide. Endocrinology. 130:229-239.

33. Greenwald, J. E., M. Sakata, M. L. Michener, S. D. Sides, and P. Needleman. 1988. Is atriopeptin a physiological or pathophysiological substance? Studies in the autoimmune rat. J. Clin. Invest. 81:1036-1041.

34. Morishita, Y., T. Sano, K. Ando, Y. Saitoh, H. Kase, K. Yamada, and Y. Matsuda. 1991. Microbial polysaccharide, HS-142-1, competitively and selectively inhibits ANP binding to its guanylyl cyclase-containing receptor. Biochem. Biophys. Res. Commun. 176:949-957.

35. Morishita, Y., T. Sano, H. Kase, K. Yamada, T. Inagami, and Y. Matsuda. 1992. HS-142-1, a novel nonpeptide atrial natriuretic peptide (ANP) antagonist, blocks ANP-induced renal responses through a specific interaction with guanylyl cyclase-linked receptors. Eur. J. Pharmacol. 225:203-207.

36. Tanaka, T., M. Ichimura, S. Nakajo, R. M. Snajdar, Y. Morishita, T. Sano, K. Yamada, T. Inagami, and Y. Matsuda. 1992. HS-142-1, a novel non-peptide antagonist for atrial natriuretic peptide receptor, selectively inhibits particulate guanylyl cyclase and lowers cyclic GMP in LLC-PK1 cells. Biosci. Biotechnol. Biochem. 56:1041-1045.

37. Sano, T., Y. Morishita, Y. Matsuda, and K. Yamada. 1992. Pharmacological profile of HS-142-1, a novel nonpeptide atrial natriuretic peptide antagonist of microbial origin. I. Selective inhibition of the actions of natriuretic peptides in anesthetized rats. J. Pharmacol. Exp. Ther. 260:825-831.

38. Sarda, I. R., M. L. de Bold, and A. J. de Bold. 1989. Optimization of atrial natriuretic factor radioimmunoassay. Clin. Biochem. 22:11-15.

39. Bruneau, B. G., and A. J. de Bold. 1994. Selective changes in natriuretic peptide and early response gene expression in isolated rat atria following stimulation by stretch or endothelin-1. Cardiovasc. Res. In press.

40. Mangat, H. and A. J. de Bold. 1993. Stretch-induced atrial natriuretic factor release utilizes a rapidly depleting pool of newly synthesized hormone. Endocrinology. 133:1398-1403.

41. Gardner, D. G., B. J. Gertz, C. F. Deschepper, and D. Y. Kim. 1988. Gene for the rat atrial natriuretic peptide is regulated by glucocorticoids in vitro. $J$. Clin. Invest. 82:1275-1281.

42. Funder, J. W., D. Duval, and P. Meyer. 1973. Cardiac glucocorticoid receptor: the binding of tritiated dexamethasone in rat and dog heart. Endocrinology. 93:1300-1308.

43. Kuroski de Bold, M. L., O. Pulido, G. Dubé, B. Fernandez, and A. J. de Bold. 1992. Morphological and biochemical studies on the subcellular distribution of A- and B-type natriuretic factors in the rat heart. FASEB (Fed. Am. Soc. Exp. Biol.) J. 6(Pt. I):A1234 (Abstr.)

44. Suzuki, E., Y. Hirata, O. Kohmoto, T. Sugimoto, H. Hayakawa, H. Matsuoka, M. Kojima, K. Kangawa, N. Minamino, and H. Matsuo. 1992. Cellular mechanisms for synthesis and secretion of atrial natriuretic peptide and brain natriuretic peptide in cultured rat atrial cells. Circ. Res. 71:1039-1048.

45. Mukoyama, M., K. Nakao, K. Hosoda, S. Suga, Y. Saito, Y. Ogawa, G. Shirakami, M. Jougasaki, K. Obata, H. Yasue, et al. 1991. Brain natriuretic peptide as a novel cardiac hormone in humans. Evidence for an exquisite dual natriuretic peptide system, atrial natriuretic peptide and brain natriuretic peptide. J. Clin. Invest. 87:1402-1412.

46. Ogawa, Y., K. Nakao, M. Mukoyama, K. Hosoda, G. Shirakami, H. Arai, Y. Saito, S. Suga, M. Jougasaki, and H. Imura. 1991. Natriuretic peptides as cardiac hormones in normotensive and spontaneously hypertensive rats. The ventricle is a major site of synthesis and secretion of brain natriuretic peptide. Circ. Res. 69:491-500.

47. Kohno, M., T. Horio, K. Yokokawa, K. Murakawa, K. Yasunari, K. Akioka, A. Tahara, I. Toda, K. Takeuchi, N. Kurihara, et al. 1992. Brain natriuretic peptide as a cardiac hormone in essential hypertension. Am. J. Med. 92:29-34.

48. Richards, A. M., I. G. Crozier, E. A. Espiner, T. G. Yandle, and M. G. Nicholls. 1993. Plasma brain natriuretic peptide and endopeptidase 24.11 inhibition in hypertension. Hypertension (Dallas). 22:231-236.

49. Lang, C. C., A. M. J. Choy, K. Turner, R. Tobin, W. Coutie, and A. D. Struthers. 1993. The effect of intravenous saline loading on plasma levels of brain natriuretic peptide in man. J. Hypertens. 11:737-741.

50. Hirata, Y., H. Matsuoka, E. Suzuki, H. Hayakawa, T. Sugimoto, Y. Matsuda, Y. Morishita, K. Kangawa, N. Minamino, and H. Matsuo. 1993. Role of endogenous atrial natriuretic peptide in DOCA-salt hypertensive rats. Effects of a novel nonpeptide antagonist for atrial natriuretic peptide receptor. Circulation. 87:554-561.

51. Yokota, N., Y. Yamamoto, K. Kitamura, K. Kangawa, N. Minamino, H. Matsuo, and T. Eto. 1993. Alterations in circulating and cardiac tissue concentrations of brain natriuretic peptides in spontaneously hypertensive rats. Cardiovasc. Res. 27:1312-1315. 
52. Yokota, N., M. L. Kuroski de Bold, and A. J. de Bold. 1993. Transcriptional and post-translational regulation of atrial natriuretic factor (ANF) and brain natriuretic peptide (BNP) during the development of DOCA-salt hypertension. Circulation. 88(Suppl. 1):1315(Abstr.)

53. Maack, T., M. Suzuki, F. A. Almeida, D. Nussenzveig, R. M. Scarborough, G. A. McEnroe, and J. A. Lewicki. 1987. Physiological role of silent receptors of atrial natriuretic factor. Science (Wash. DC). 238:675-678.

54. Lafferty, H. M., M. Gunning, P. Silva, M. B. Zimmerman, B. M. Brenner, and S. Anderson. 1989. Enkephalinase inhibition increases plasma atrial natriuretic peptide levels, glomerular filtration rate, and urinary sodium excretion in rats with reduced renal mass. Circ. Res. 65:640-646.

55. Broadus, A. E., N. L. Kaninski, J. G. Hardman, E. W. Sutherland, and G. W. Liddle. 1970. Kinetic parameters and renal clearances of plasma adenosine $3^{\prime}, 5^{\prime}$-monophosphate and guanosine $3^{\prime}, 5^{\prime}$-monophosphate in man. J. Clin. Invest. 49:2222-2236.

56. Wong, K. R., M. H. Xie, L. B. Shi, F. Y. Liu, C. L. Huang, D. G. Gardner, and M. G. Cogan. 1988. Urinary cGMP as biological marker of the renal activity of atrial natriuretic factor. Am. J. Physiol. 255:F1220-F1224.

57. Hirata, Y., H. Matsuoka, H. Hayakawa, T. Sugimoto, E. Suzuki, K. Kangawa, and H. Matsuo. 1991. Role of endogenous atrial natriuretic peptide in regulating sodium excretion in spontaneously hypertensive rats-effects of neutral endopeptidase inhibition. Hypertension (Dallas). 17:1025-1032.

58. Farman, N. 1992. Steroid receptors: distribution along the nephron. Semin. Nephrol. 12:12-17.

59. Terada, Y., and M. A. Knepper. 1989. $\mathrm{Na}^{+}, \mathrm{K}^{+}$-ATPase in renal tubule segments of rat inner medulla. Am. J. Physiol. 256:F218-F223.

60. Gaillard, C. A., H. A. Koomans, T. J. Rabelink, B. Braam, P. Boer, and E. J. Dorhout Mees. 1988. Enhanced natriuretic effect of atrial natriuretic factor during mineralocorticoid escape in humans. Hypertension (Dallas). 12:450-456.
61. Maack, T., M. J. F. Camargo, H. D. Kleinert, J. H. Laragh, and S. A. Atlas. 1985. Atrial natriuretic factor: structure and functional properties. Kidney Int. 27:607-615.

62. Burnett, J. C., Jr., J. P. Granger, and T. J. Opgenorth. 1984. Effects of synthetic atrial natriuretic factor on renal function and renin release. Am. J. Phys iol. 247:F863-F866.

63. Kleinert, H. D., T. Maack, S. A. Atlas, A. Januszewicz, J. E. Sealey, J. H. Laragh. 1984. Atrial natriuretic factor inhibits angiotensin-, norepinephrine-, and potassium-induced vascular contractility. Hypertension (Dallas). 6(Suppl. 1): I143-I147.

64. Kiberd, B. A., T. S. Larson, C. R. Robertson, and R. L. Jamison. 1987 Effect of atrial natriuretic peptide on vasa recta blood flow in the rat. Am. J. Physiol. 252:F1112-F1117.

65. Zeidel, M. L., J. L. Seifter, S. Lear, B. M. Brenner, and P. Silva. 1986. Atrial peptides inhibit oxygen consumption in kidney medullary collecting duct cells. Am. J. Physiol. 251:F379-F383.

66. Light, D. B., E. M. Schwiebert, K. H. Karlson, and B. A. Stanton. 1989. Atrial natriuretic peptide inhibits a cation channel in renal inner medullary collecting duct cells. Science (Wash. DC). 243:383-385.

67. Sasaki, A., O. Kida, K. Kangawa, H. Matsuo, and K. Tanaka. 1986. Involvement of sympathetic nerves in cardiosuppressive effects of alpha-human atrial natriuretic polypeptide (alpha-hANP) in anesthetized rats. Eur. J. Pharmacol. 120:345-349.

68. Koseki, C., Y. Hayashi, S. Torikai, M. Furuya, N. Ohmura, and M. Imai. 1986. Localization of binding sites of $\alpha$-rat atril natriuretic polypeptide in rat kidney. Am. J. Physiol. 250:F210-F216.

69. Trippodo, N. C., F. E. Cole, A. A. MacPhee, and B. L. Pegram. 1987. Biologic mechanisms of atrial natriuretic factor. J. Lab. Clin. Med. 109:112-119. 